\title{
The Effects of Adjunctive Steroids in the Treatment of Peritonsillar Abscess
}

\author{
Junyong Choi, Dongsik Chang, Minwoo Kim, Jun Lee, and Myoungsu Choi \\ Department of Otolaryngology-Head and Neck Surgery, Eulji University Medical Center, Eulji University School of Medicine, \\ Daejeon, Korea
}

편도주위농양 치료 시 부가적 스테로이드의 효과

최준용 · 장동식 · 김민우 · 이 준 · 최명수

을지대학교 의과대학 이비인후과학교실

\author{
Received March 13, 2020 \\ Revised August 11,2020 \\ Accepted August 13, 2020 \\ Address for correspondence \\ Myoung Su Choi, MD \\ Department of Otolaryngology- \\ Head and Neck Surgery, \\ Eulji University Medical Center, \\ Eulji University School of Medicine, \\ 95 Dunsanse-ro, Seo-gu, \\ Daejeon 32233, Korea \\ Tel $+82-42-611-3129$ \\ Fax $+82-42-611-3136$ \\ E-mail mschoi@eulji.ac.kr
}

Background and Objectives Steroids have strong anti-inflammatory, anti-edema, and antipyretic effects. Since there are few studies on the use of steroids in the treatment of peritonsillar abscess in Korea, we aimed at this study to investigate the effects of steroids along with antibiotics in the treatment of peritonsillar abscess.

Subjects and Method A retrospective study was conducted on 75 patients who were admitted from 2014 to 2019. Between 2014 and 2017, only antibiotics were administrated after incisional drainage (no-use group), but between 2018 and 2019, antibiotics and adjunctive steroids were administrated after incisional drainage (steroids group). Symptoms of patients, blood tests, diets available, and hospitalization period were compared between the two groups.

Results The length of hospital stay for the steroids group $(n=24)$ and the no-use group $(n=51)$ was $4.2 \pm 1.3$ days and of $5.1 \pm 1.8$ days $(p=0.046)$, respectively, showing significantly shortened time for the steroids group. The rate of change in 48 -hour C-reactive protein was $53.3 \%$ and $20 \%$ for the steroid group and no-use group $(p=0.013)$, respectively. However, there was no differences between the two groups in the rate of change in body temperature at 12 hours of treatment, the diet available at 12 hours, and rate of change in the number of white blood cells after 48 hours of treatment.

Conclusion Adjunctive steroids for peritonsillar abscess can be a useful treatment that shows rapid improvement of symptoms and C-reactive protein, and shorter hospitalization periods. Korean J Otorhinolaryngol-Head Neck Surg 2021;64(8):563-7

Key Words C-reactive protein · Peritonsillar abscess $\cdot$ Steroid.

\section{서 론}

편도주위농양은 소아나 젊은 성인에서 가장 흔한 심경부 감염증이다. ${ }^{1,2)}$ 미국에서는 연간 45000 건의 편도주위농양이 발생하며 100000 명당 30 명의 유병률을 보이고 있다. ${ }^{3)}$ 편도 주위농양은 급성 편도선염의 화농성 합병증으로, 급성 편도

This is an Open Access article distributed under the terms of the Creative Commons Attribution Non-Commercial License (https://creativecommons.org/licenses/by-nc/4.0) which permits unrestricted non-commercial use, distribution, and reproduction in any medium, provided the original work is properly cited.
선염이 진행하여 편도주위염으로, 종결에는 편도 주위 공간 에 농양을 형성하는 일련의 과정을 거친다. 편도주위농양은 진단이 늦어지거나 적절한 치료가 이루어지지 않으면, 기도 폐색, 심경부 감염, 패혈증, 종격동염 등을 일으킬 수 있어 주 의를 요한다. ${ }^{4)}$ 조기에 절개배농 및 항생제 치료가 주된 치료 로 알려져 있다.

또한, 편도주위농양은 상인두나 저작공간 부종을 일으켜 입벌림장애(trismus), 삼킴통증(odynophagia) 같은 2차적인 증상을 야기하고 이로 인해 경구 섭취가 저해되고 탈수 등의 
문제로 입원 치료를 요하기도 한다. ${ }^{2)}$ 항생제 사용과 농양배 농술을 시행함에도 불구하고 편도주위농양 환자는 상당 기 간 인후통과 삼킴곤란 같은 불편한 증상을 호소하기도 한다. 이러한 증상을 경감시키기 위해서 항생제와 더불어 스테로이 드 사용이 시도되어 왔다. ${ }^{5-10)}$ 스테로이드는 부종을 줄이는 데 효과가 있다고 알려져 있어서 기도 폐색이 의심되는 환자에 서는 널리 사용되었으며,11) 여러 특발성 또는 바이러스성 이 비인후과 질환에서도 그 효능을 입증해왔다. ${ }^{11-13)}$ 그러나, 급성 세균성 염증 치료 시 스테로이드 사용은 도리어 면역을 억제 하여 치료를 지연시키거나 악화시킬 수 있다는 우려 때문에 스테로이드 사용을 임상 의사들은 꺼려왔다. 2000년에 이를 때까지도 편도주위농양 치료에 스테로이드 사용이 보고된 바 없었으나, 2004년도에 터키 의사 Ozbek 등)이 최초로 편 도주위농양 환자를 대상으로 바늘로 농양을 흡인 후 항생제 와 더불어 스테로이드 사용을 보고하였다.

저자들은 국내에서 편도주위농양 치료에 스테로이드 사용 에 대한 연구가 많지 않아, 편도주위농양 치료에 있어 농양배 농 후, 항생제와 더불어 스테로이드 사용이 삼킴통증, 입벌림 장애 같은 임상 증상과 여러 혈액검사 수치에 어떤 영향을 주는지 또한 이런 임상 지표들이 퇴원 시기에 어떤 영향을 주는지 알아보기 위해서 이 연구를 계획하였다.

\section{대상 및 방법}

2014년 1월 2019년 12월까지 6년간 본원에 내원하여 편도 주위농양으로 진단받아 입원 치료했던 환자들의 진료 기록을 대상으로 후향적 연구를 시행하였다. 본 연구는 을지대학교 을지대학교병원 임상시험위원회(Institutional Review Board) 의 승인 후 진행되었다(IRB No. EMC 2020-03-005).

환자는 임상적으로 편도 주위 부종과 목젖의 편위가 관찰 되며 CT상 편도 주위 공간에 명백한 농양이 관찰되거나 ${ }^{14}$ 또 는, 굵은 바늘로 병변에 흡인하여 농양을 확인한 경우에는 편도주위농양으로 진단하였다. 편도주위농양으로 확인된 경 우에는 바늘로 흡인하여 농양을 확인한 부위를 절개 배농하 고 배액관을 삽입하였으며, 배액관은 방사능 표지자가 피복 되어 있는 실리콘 튜브를 재단하여 사용하였다. 편도주위농 양으로 입원한 환자들은 광범위 항생제 Augmentin(amoxicillin and clavulanate) $3.6 \mathrm{~g}$ (Ilsung, Seoul, Korea)을 하루 3 회 나누어 정주하였으며, Augmentin에 부작용이 있는 경우 에는 경험적으로 Ceftriaxone $2 \mathrm{~g}$ (Boryung, Seoul, Korea) 을 하루 1회, Flazyl(metronidazole) $1.5 \mathrm{~g}$ (Albogen, Seoul, Korea)을 병합요법으로 하루 3회 나누어 정주하였으며, 균동 정 결과에 따라 감수성 있는 항생제로 바꾸어 치료하였다.
환자의 선정기준은 2014년 1월 2019년 12월까지 편도주위 농양으로 입원 치료받은 자이며, 제외기준은 편도주위염, 부 인두농양이나 다른 심경부 농양이 같이 진단되어 치료받은 자, 경부종물의 감염으로 진단되어 치료받은 자는 제외하였다.

2014년 1월 2017년 12월까지는 입원한 환자들에게 절개배 농 후 항생제만 사용하였으며, 2018년 1월 2019년 12월까지 는 절개배농 후 항생제와 더불어 부가적 스테로이드를 같이 사용하였다. 스테로이드는 입원 첫날 dexamethasone $5 \mathrm{mg}$ (Huons, Seongnam, Korea)을 1회 정주하였으며, 입원 4일 째까지 하루에 $10 \mathrm{mg}$ prednisolone(Yuhan, Seoul, Korea) 을 경구투여하였다. 조절되지 않은 당뇨병 환자와 기타 스테 로이드 사용 금기증 환자에서는 사용하지 않았으며, 소화성 궤양이나, 기타 스테로이드 부작용 등이 의심되면 즉시 중단 하였다.

스테로이드를 항생제와 같이 사용한 그룹과 사용하지 않은 그룹으로 나누어서 입원 시 환자의 증상, 혈액검사 결과, 식이 가능한 종류, 체온, 입원 기간 등을 비교하였다.

퇴원기준은 '삼킴통증과 같은 임상 증상의 뚜렷한 호전을 보이고, 이학적 소견상 편도 주위 부종의 확연한 감소와 경부 로 편도 부위를 손으로 눌렀을 때 압통의 호전'을 퇴원기준으 로 하였다. 아울러 $\mathrm{C}$-반응단백의 확연한 감소도 참조하였다.

$\mathrm{C}-$ 반응단백의 48 시간동안 변동률을 다음과 같은 공식으 로 구하였다.

변동율 $=\{($ 입원 당시 혈액검사 수치 $)-(48$ 시간째 혈액검사 수치 $)\} /($ 입원 당시 혈액검사 수치 $) \times 100(\%)$

\section{통계 분석}

통계 분석은 SPSS 18.0(SPSS Inc., Chicago, IL, USA)을 사용하였으며, 두 그룹 간에 입원 기간, 체온, 혈액검사 결과 를 t-test, paired t-test를 이용하여 비교하였으며, 12시간 후 식이 진행 여부를 chi-square test를 이용하여 비교하였다. $p$ 값은 0.05 이하를 유의하다고 정하였다.

\section{결 과}

편도주위농양으로 입원 치료한 환자들의 특성을 Table 1에 정리하였다. 연구에 포함된 환자 수는 75명(mean age: 35.7 \pm 14.8 , 남성 49명, 여성 26명)이다. 부가적 스테로이드를 사용

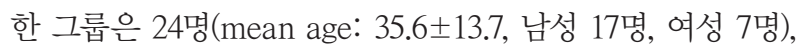

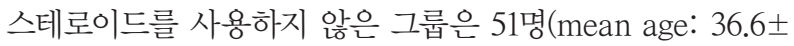
16.9 , 남성 32명, 여성 19명)이다. 두 그룹은 성별과 나이에서 통계적 차이를 보이지 않았다 $(p=0.492,0.795)$. 입원한 환자 
들의 주 증상은 삼킴곤란이 $90.7 \%$ 로 가장 높았으며, 발열과 오한이 $33.3 \%$, 입벌림곤란이 $16.0 \%$ 로 확인되었다. 퇴원 시 환 자의 삼킴곤란은 확연히 호전되었으며, 입벌림곤란도 모두 회 복되었다. 입원 시 입벌림곤란을 호소한 환자는 스테로이드 사용군에서 4 명, 사용하지 않은 군에서 8 명으로 총 12 명이었 으며, 치료 48시간 경과 후 스테로이드 사용군에서는 3명이 호전되고, 사용하지 않은 군에서는 4명이 호전된 상태로 두 군간에는 유의한 차이를 보이지 않았다 $(p=1.000$ )(Table 2).

입원 기간은 스테로이드를 사용한 그룹에서는 $4.2 \pm 1.3$ 일, 사용하지 않은 그룹은 $5.1 \pm 1.8$ 일로 스테로이드를 사용한 그 룹에서 유의하게 단축된 것으로 나타났다 $(p=0.046)$ (Table 2). 혈액검사상, $\mathrm{C}-$ 반응단백은 입원 시에는 스테로이드 사용 그 룹과 사용하지 않은 그룹 간에 유의한 차이를 보이지 않았으 며 $(p=0.250)$, 입원 치료 후 48시간이 경과한 시점에서는 두 그 룹이 치료 후 유의하게 호전되었다 $(p=0.047)$ (Table 2). C-반

Table 1. Clinical characteristics of patients $(n=75)$

\begin{tabular}{lc}
\hline Age (years) & $35.7 \pm 14.8$ \\
Male:female & $49: 26$ \\
Symptoms (\%) & \\
$\quad$ Difficulty swallowing & $68(90.7)$ \\
Difficulty opening the mouth & $12(16.0)$ \\
Fever and chills & $25(33.3)$ \\
Swelling of neck & $11(14.7)$ \\
$\quad$ Muffled voice & $11(14.7)$ \\
Unilateral:bilateral (\%) & $68: 7(90.7: 9.3)$ \\
\hline
\end{tabular}

Table 2. Comparison of various parameters of two groups

\begin{tabular}{lccc}
\hline & Steroid $(\mathrm{n}=24)$ & Control $(\mathrm{n}=51)$ & $\mathrm{p}$-value \\
\hline Male:female & $17: 7$ & $32: 19$ & 0.492 \\
Age (years) & $35.6 \pm 13.7$ & $36.6 \pm 16.9$ & 0.795 \\
$\mathrm{HTN}$ & $3(12.5)$ & $5(9.8)$ & 0.705 \\
$\mathrm{DM}$ & $1(4.2)$ & $3(5.9)$ & 1.000 \\
Initial-WBC $\left(10^{9} / \mathrm{L}\right)$ & $14.46 \pm 5.03$ & $12.58 \pm 4.36$ & 0.122 \\
$48 \mathrm{hr}-\mathrm{WBC}\left(10^{9} / \mathrm{L}\right)$ & $10.23 \pm 3.08$ & $8.06 \pm 3.05$ & 0.024 \\
Initial-CRP $(\mathrm{mg} / \mathrm{L})$ & $10.0 \pm 7.0$ & $8.3 \pm 4.9$ & 0.250 \\
$48 \mathrm{hr}-\mathrm{CRP}(\mathrm{mg} / \mathrm{L})$ & $4.2 \pm 2.4$ & $5.7 \pm 3.6$ & 0.047 \\
Initial-BT $\left({ }^{\circ} \mathrm{C}\right)$ & $37.2 \pm 0.5$ & $37.0 \pm 0.6$ & 0.346 \\
Initial-trismus & $4(16.7)$ & $8(15.9)$ & 1.000 \\
$48 \mathrm{hr}-$ trismus & $1(4.2)$ & $4(7.8)$ & 1.000 \\
Hospital stays $($ days $)$ & $4.2 \pm 1.3$ & $5.1 \pm 1.8$ & 0.046 \\
Re-admission & $3(12.5)$ & $4(7.8)$ & 0.673 \\
Diet available at $12 \mathrm{~h}$ & & & 0.849 \\
$\quad$ Regular & $12(50.0)$ & $21(41.2)$ & \\
Soft & $8(33.3)$ & $17(33.3)$ & \\
Fasting & $4(16.7)$ & $13(25.5)$ &
\end{tabular}

Data are presented as $n(\%)$. HTN: hypertension, DM: diabetes mellitus, WBC: white blood cell count, CRP: C-reactive protein, BT: body temperature, h: hour
응단백의 처음 48 시간 변동율은 스테로이드를 사용한 그룹 에서는 $53.3 \%$, 사용하지 않은 그룹에서는 $20 \%$ 로 두 그룹에 서는 유의한 차이를 보였다 $(p=0.013)$.

혈액검사상 백혈구 수는 입원 당시, 스테로이드를 사용한 그룹과 사용하지 않은 그룹 간에 유의한 차이를 보이지 않았 으며 $(p=0.122)$, 입원 치료 후 48시간 경과한 시점에서는 두 그룹이 치료 후 유의하게 호전되었다 $(p=0.024)$ (Table 2). 또 한, 백혈구 수의 변동율은 스테로이드 그룹에서 $28.5 \%$, 사용 하지 않은 그룹에서는 $31.2 \%$ 로 유의한 차이를 보이지 않았 다 $(p=0.747)$.

입원 시 환자의 체온은 스테로이드 그룹 $37.2^{\circ} \mathrm{C}$, 사용하지 않은 그룹 $37.0^{\circ} \mathrm{C}$ 로 유의한 차이가 나지 않았으며 $(p=0.346)$, 재원 중에도 체온은 두 그룹 사이에 차이를 보이지 않았다.

입원 후 12 시간 경과 후 섭취 가능한 식사는 Table 2 와 같 았다. 입원 후 12 시간 경과 후 스테로이드 그룹에서 금식을 하는 비율이 $16.7 \%$, 사용하지 않은 그룹은 $25.5 \%$ 로 스테로이 드 사용 그룹에서 금식 비율이 낮았다.

\section{고 찰}

이번 연구를 통해서 부가적 스테로이드 치료는 편도주위 농양 치료에 있어서 스테로이드를 사용하지 않은 경우와 비 교하여 입원 기간을 줄일 수 있음을 보여주었다. 이는 국외의 다른 연구 결과들과 일치한다. Ozbek 등 ${ }^{5}$ 은 62 명의 편도주 위농양 환자 치료에 전향적으로 바늘로 농양을 흡인 후, 항생 제와 더불어 위약을 사용한 그룹과 스테로이드를 사용한 그 룹으로 나누었다. 치료 4일 내에 퇴원하는 비율이 스테로이드 사용 그룹이 $84 \%$, 사용하지 않은 그룹은 $22 \%$ 로 스테로이드 사용 그룹에서 입원 기간이 유의하게 단축됨을 보였다. Koçak 등 ${ }^{10)}$ 의 연구에서는 후향적 연구를 통해서 절개배농 후 스테 로이드를 사용한 그룹에서 입원 기간이 평균 1.2 일로 사용하 지 않은 그룹 2.6일에 비해 유의하게 단축되고, 경구 식이 시 작 시간도 스테로이드 사용한 그룹은 6.3시간, 사용하지 않은 그룹 17.2시간에 비해 유의하게 앞당길 수 있었다. Chau 등하 은 환자가 보고하는 설문지 연구를 통해서 편도주위농양에서 스테로이드 사용한 그룹과 위약 사용한 그룹의 통증을 24시 간째, 48시간째, 7일째 비교하였다. 24시간째 통증점수가 스 테로이드 그룹은 1.4 로 위약 그룹 3.7에 비해 유의하게 호전된 것을 보였으나, 48시간이나 7일째는 두 그룹 사이에 차이를 보이지 않았다. 스테로이드 사용은 경구 통증을 감소시키고, 통증없는 식이를 앞당겨 환자의 주관적 만족감을 높이고 결 국 치료 기간을 줄일 수 있게 된다. 본 연구에서는 삼킴통증 을 정량적으로 체크하지 못하여 추후 연구가 필요한 실정이 
나, 환자가 12 시간째 진행한 식이 종류를 확인함으로써 간접 적으로 삼킴통증을 비교해 볼 수 있었다. 정상식이와 연식을 진행한 비율이 스테로이드 사용 그룹에서 $83.3 \%$, 사용하지 않은 그룹은 $74.5 \%$ 로 평균은 높았지만 통계적으로 유의하지 는 않았다.

본 연구에서는 C-반응단백과 백혈구 수와 같은 혈액검사 수치를 비교하였다. 이는 기존의 연구에서는 다루지 않았던 지표로서, 환자가 스스로 보고하는 주관적 증상 점수를 뒷받 침할 수 있는 객관적 근거가 될 수 있다. 본 연구에서는 치료 후 48시간째 시행한 검사 수치의 변화율을 구하였다. 백혈구 수 변화율은 48시간째 두 그룹 간에 유의한 차이를 보이지 않았다. C-반응단백은 스테로이드 사용한 그룹에서는 치료 후 48 시간째 스테로이드 사용그룹은 $53.3 \%$ 감소하였으며, 사용하지 않은 그룹은 $23 \%$ 감소하여 스테로이드 사용 그룹 에서 유의하게 C-반응단백이 큰 폭으로 호전된 것을 알 수 있었다(Fig. 1). C-반응단백은 급성기 반응물질 중 하나로 감 염, 손상, 수술, 외상, 조직괴사 시 증가하며 손상받은 세포의 표면이나 세균 등의 표면에 침강반응을 일으키며 급성기 반 응물질 중 가장 먼저 증가하고 치료 시 가장 먼저 정상화되는 특징을 가지고 있어 술후 치료 효과, 염증반응의 추적, 심부 감염이나 포도상구균 균혈증의 조기 발견의 예측 인자로도 사용된다. ${ }^{15)}$ 편도주위농양 퇴원을 결정에 있어서도, 편도 주 위 부종의 감소와 삼킴곤란이나 압통감소 등의 이학적, 주관 적 소견과 더불어 $\mathrm{C}$-반응단백 호전은 중요한 지표가 되어왔 으며, 스테로이드 그룹에서 빠른 C-반응단백 호전율은 입원 기간 단축에 관련된 것으로 보인다.

Chau 등은 편도주위농양 치료 시 스테로이드 부가 사용 은 치료 24시간째 체온이 유의하게 정상적으로 낮아짐을 보 였다. Ozbek 등 ${ }^{5}$ 도 치료 24시간째 체온이 정상화되는 비율이 스테로이드 사용 그룹에서 $86 \%$, 사용하지 않은 그룹이 $28 \%$

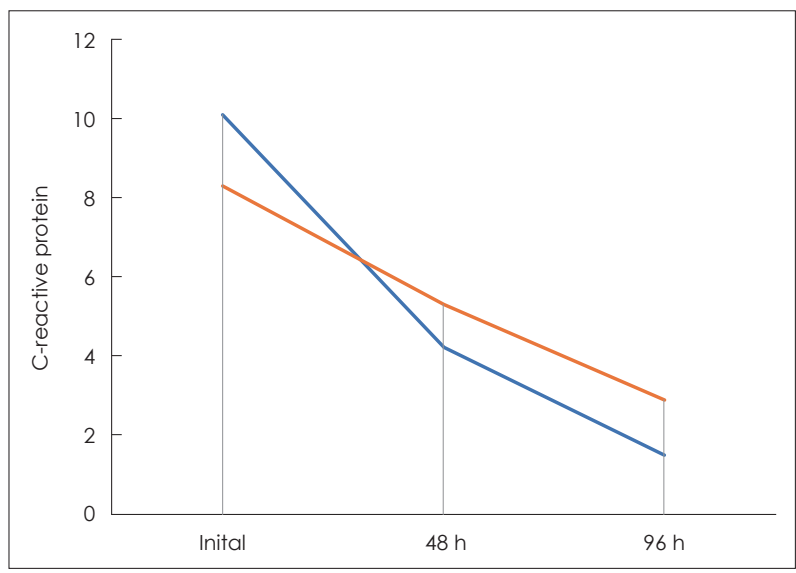

Fig. 1. C-reactive protein decreased steeply over time in the adjunctive steroid treatment group compared to the non-use group.
로 유의한 차이를 보였다. 메타분석 연구에서도 치료 24시간 째 스테로이드 사용한 그룹에서는 유의하게 체온이 정상화 되는 비율이 높았으나, 치료 48시간째에는 그러한 효과는 더 지속되지는 않는다고 보고하였다. ${ }^{8)}$ 본 연구에서는 기존의 연 구와 다른 결과를 보였다. 입원 당시 체온을 비교하면, $37^{\circ} \mathrm{C}$ 정도로 발열이 심하지 않은 편이다. 우리나라 의료 사정상 환 자들의 병원 방문이 비교적 용이하고, 의원급에서도 조기에 항생제를 처방받는 경우가 많기 때문에 2 차, 3 차 병원 내원 시에는 체온이 정상이거나 약간 높게 나타나는 정도여서, 스 테로이드의 치료 효과를 알기 어려울 정도여서, 다른 연구와 상반된 결과를 보인 것으로 추정한다.

스테로이드는 성대부종, Bell 안면마비, 돌발성 난청, 급성 후두개염 등 여러 염증성 이비인후과 질환 치료에 이미 사용 되어왔다. ${ }^{11-13)}$ 스테로이드는 강력한 항염증 작용과 항부종 작용 그리고 해열작용을 가지고 있다. ${ }^{16)}$ 급성 후두개염 치료 에서 항생제 치료와 더불어 스테로이드 치료는 중환자실 재 원 기간을 줄이고 전체 입원 기간 감소에 도움이 된다고 알려 져 있다. ${ }^{11)}$ 급성 농양은 중성구(neutrophil) 등의 단백질분해 (proteolysis)작용으로 인한 액화괴사(liquefactive necrosis) 과정의 산물로 생성된다. 스테로이드는 phospholipase A2 효소를 차단하는 기능이 있으며, 이로 인해 leukotrienes와 prostaglandins 생성을 억제하고 결과적으로 이 염증 매개물 질들의 감소는 중성구의 단백질분해를 감소시켜 부종과 농 양형성을 저해한다. ${ }^{17)}$

그러나 스테로이드의 효능을 알고 있으면서도 편도주위농 양에서의 스테로이드 사용은 그간 논란이 있어왔다. ${ }^{18)}$ 스테로 이드 사용이 면역을 저하시켜서 편도주위농양을 심경부농양 으로 발전시킬 수 있다는 우려와 소아에서 사용제한 및 농양 의 재발율 증가 등이 거론되어 왔다.,18) 그러나 우리 연구 포 함하여 2개의 메타연구에서 모두 편도주위농양 치료에서 스 테로이드 사용으로 이러한 부작용은 한 건도 보고되지 않았 다.8) 사용한 스테로이드 용량도 연구자에 따라서 다양하였 는데, Chau 등은 $10 \mathrm{mg}$ dexamethasone, Koçak 등 ${ }^{10)}$ 은 1 $\mathrm{mg} / \mathrm{kg}$ methylprednisolone, Ozbeck 등 ${ }^{5}$ 은 2 3 mg/kg 최대 $250 \mathrm{mg}$ 까지의 methylprednisolone을 모두 농양배농술 시행 후 1 회 정주하였다. 위와 같이 스테로이드 용량은 다양하였 지만 대부분 1 회 정주하였기 때문에, 치료 후 24 시간째 임상 증상 호전이 두드러졌다. 24시간째 체온, 통증, 입벌림정도 등 의 지표에서 호전을 보이는 경우가 많았으나, 치료 후 48시간 째 이후에는 그러한 효과는 스테로이드를 사용하지 않는 그 룹과 비교해서는 더는 차이 나지 않는다고 보고하였다. 우리 연구에서는 농양배농술 후 1 회 $5 \mathrm{mg}$ dexamethasone을 정 주한 후, 입원 4일째까지 하루 $10 \mathrm{mg}$ 의 prednisolone을 경구 
투여하여 입원기간의 유의한 단축과 $\mathrm{C}$-반응단백의 뚜렷한 감소율을 보였으며, 속쓰림이나 심경부감염과 같은 부작용은 없었으며, 재발하여 재입원하는 경우도 스테로이드 사용 그 룹에서는 3 명, 사용하지 않은 그룹에서는 4명으로 유의한 차 이를 보이지 않았다. 퇴원 후 재입원까지 평균 소요 기간은 스 테로이드 그룹에서는 9일, 사용하지 않은 그룹에서는 11일로 유의한 차이를 보이지 않았다. 재발한 원인을 추정하면, 농양 배농술 못지않게 감수성 있는 항생제 선택이 중요한데, 균배 양검사상 균동정이 되지 않았거나, 입원 기간에는 결과가 나 오지 않아서, 경험적으로만 항생제를 선택해서 사용한 경우 세균에 대한 감수성이 떨어져서 퇴원 후 항생제 사용 중단으 로, 염증이 다시 재발한 것으로 추정한다.

본 연구는 후향적 연구로서 연구자의 선입견이나 자료의 선택 등의 단점을 갖고 있다. 특히, 조절되지 않은 당뇨병 환 자에서는 스테로이드 사용이 제한되어 비록 3명이라는 적은 수이지만 '사용하지 않은 그룹’으로 포함되었으며, 혈당이 잘 조절된 환자 1 명은 '스테로이드 그룹'으로 포함되어 치료가 어 려운 환자가 '사용하지 않은 그룹'으로 포함되는 선택 편위가 발생하기도 하였다. 그럼에도 불구하고, 스테로이드 사용그룹 과 사용하지 않은 그룹 간에 초기 C-반응단백 수치, 백혈구 수치, 나이, 성별 등 두 그룹 간에 차이가 유의하지 않았기 때 문에 이러한 단점을 최소화하였다. 추후 전향적 연구를 통해 서 이를 보완해야 할 것으로 판단한다.

편도주위농양 치료에 있어서 부가적 스테로이드 치료는 임 상증상과 더불어 $\mathrm{C}-$ 반응단백의 신속한 호전을 보였으며, 입 원 기간을 유의하게 단축할 수 있어, 유용한 치료법으로 생 각한다.

\section{Acknowledgments}

None.

\section{Author Contribution}

Conceptualization: Myoungsu Choi. Data curation: Minwoo Kim, Junyong Choi. Methodology: Jun Lee, Dongsik Chang. Writing — original draft: Myoungsu Choi. Writing_review \& editing: Dongsik Chang, Myoungsu Choi.

\section{ORCID}

Myoung Su Choi https://orcid.org/0000-0003-4553-7808

\section{REFERENCES}

1) Steyer TE. Peritonsillar abscess: Diagnosis and treatment. Am Fam
Physician 2002;65(1):93-6.

2) Khayr W, Taepke J. Management of peritonsillar abscess: Needle aspiration versus incision and drainage versus tonsillectomy. Am J Ther 2005;12(4):344-50.

3) Battaglia A, Burchette R, Hussman J, Silver MA, Martin P, Bernstein P. Comparison of medical therapy alone to medical therapy with surgical treatment of peritonsillar abscess. Otolaryngol Head Neck Surg 2018;158(2):280-6.

4) Herzon FS, Martin AD. Medical and surgical treatment of peritonsillar, retropharyngeal, and parapharyngeal abscesses. Curr Infect Dis Rep 2006;8(3):196-202.

5) Ozbek C, Aygenc E, Tuna EU, Selcuk A, Ozdem C. Use of steroids in the treatment of peritonsillar abscess. J Laryngol Otol 2004; 118(6):439-42.

6) Chau JK, Seikaly HR, Harris JR, Villa-Roel C, Brick C, Rowe BH. Corticosteroids in peritonsillar abscess treatment: A blinded placebocontrolled clinical trial. Laryngoscope 2014;124(1):97-103.

7) Lee YJ, Jeong YM, Lee HS, Hwang SH. The efficacy of corticosteroids in the treatment of peritonsillar abscess: A meta-analysis. Clin Exp Otorhinolaryngol 2016;9(2):89-97.

8) Hur K, Zhou S, Kysh L. Adjunct steroids in the treatment of peritonsillar abscess: A systematic review. Laryngoscope 2018; 128(1):72-7.

9) Powell J, Wilson JA. An evidence-based review of peritonsillar abscess. Clin Otolaryngol 2012;37(2):136-45.

10) Koçak HE, Acıpayam H, Elbistanlı MS, Yiğider AP, Alakhras WME, Kiral MN, et al. Is corticosteroid a treatment choice for the management of peritonsillar abscess? Auris Nasus Larynx 2018; 45(2):291-4.

11) Abdallah C. Acute epiglottitis: Trends, diagnosis and management. Saudi J Anaesth 2012;6(3):279-81.

12) Kim MY, Kim J. Early stage steroid treatment for acute facial paralysis in Korea. Korean J Otorhinolaryngol-Head Neck Surg 2016;59(5):346-52.

13) Park HH, Choi JH, Huh EJ, Lee TH, Nam JK, Kwon JK. Comparison of the effect of high-dose steroid with that of super-high-dose steroid therapy in sudden sensorineural hearing loss. Korean J Otorhinolaryngol-Head Neck Surg 2009;52(7):566-71.

14) Song K, Lee J, Choi SY, Choi MS. Diagnosis and treatment of peritonsillar abscess with single enhanced computed tomography. Korean J Otorhinolaryngol-Head Neck Surg 2018;61(2):99-102.

15) Sproston NR, Ashworth JJ. Role of C-reactive protein at sites of inflammation and infection. Front Immunol 2018;9:754.

16) Hayward G, Thompson M, Heneghan C, Perera R, Del Mar C, Glasziou P. Corticosteroids for pain relief in sore throat: Systematic review and meta-analysis. BMJ 2009;339:b2976.

17) Crockard AD, Boylan MT, Droogan AG, McMillan SA, Hawkins SA. Methylprednisolone-induced neutrophil leukocytosis--downmodulation of neutrophil L-selectin and Mac-1 expression and induction of granulocyte-colony stimulating factor. Int J Clin Lab Res 1998;28(2):110-5.

18) Hardman JC, McCulloch NA, Nankivell P. Do corticosteroids improve outcomes in peritonsillar abscess? Laryngoscope 2015; 125(3):537-8. 